\title{
Symptomatic palatal tremor: A descriptive cohort study of 27 cases in a tertiary hospital
}

\author{
José L. Ruíz-Sandoval1,2, ${ }^{1,}$ Erwin Chiquete-Anaya ${ }^{3}$, Germán López-Valencia' ${ }^{1}$, Arturo González-Lara ${ }^{1}$, \\ Miguel A. Andrade-Ramos ${ }^{4}$, Héctor Macías-Reyes ${ }^{5}$, Amado Jiménez-Ruiz ${ }^{3}$, and Brianda Rosas-Razo ${ }^{5}$ \\ ${ }^{1}$ Department of Neurology, Hospital Civil de Guadalajara "Fray Antonio Alcalde," Jalisco; ${ }^{2}$ Traslational Neurosciences Institute, Department of \\ Neurosciences, Centro Universitario de Ciencias de la Salud (CUCS), Universidad de Guadalajara, Guadalajara, Jalisco; ${ }^{3}$ Department of Neurology, \\ Instituto Nacional de Ciencias Médicas y Nutrición "Salvador Zubirán," Mexico City; ${ }^{4}$ Department of Neurosurgery, Hospital Civil de Guadalajara \\ "Fray Antonio Alcalde," Guadalajara, Jalisco; ${ }^{5}$ Department of Otorhinolaryngology, Hospital Civil de Guadalajara “Fray Antonio Alcalde," Guadalajara, \\ Jalisco, Mexico
}

\begin{abstract}
Background: Symptomatic palatal tremor (SPT) is an uncommon hyperkinetic movement disorder caused by the interruption of the dentato-rubro-olivary pathway due to a lesion in the brainstem or cerebellum. Methods: We describe a cohort of consecutive patients with SPT who were assessed by a single neurologist in a tertiary reference center. Results: $A$ total of 27 patients were included in this cohort from 1998 to 2016; 16 males and 11 females, with a mean age of 47 years (range 19-89). The average time from initial insult to a diagnosis of SPT was 14.5 months (range 2-48 months). The most common etiology of SPT was cerebrovascular disease (CVD) in 21 (78\%) patients. Other etiologies included infectious and demyelinating diseases of the central nervous system. The remaining unclassified case was accompanied by progressive ataxia pointing toward a neurodegenerative etiology. Twenty-six patients had a history of posterior fossa injury, and all patients had rhombencephalic signs with severe dysarthria. None of them responded significantly to pharmacological treatment. Conclusion: SPT is a more common finding than expected, especially in patients with posterior fossa injury secondary to CVD. The main clinical syndrome was the rhomboencephalic phenotype, with a predominance of dysarthria. There was no effective treatment in any of the patients.
\end{abstract}

Key words: Dysarthria. Guillain-Mollaret triangle. Hyperkinetic movement disorders. Palatal tremor. Rhomboencephalic syndrome.

\section{Temblor palatal sintomático: un estudio de cohorte descriptivo de 27 casos en un hospital terciario}

\section{Resumen}

Antecedentes: El temblor palatino sintomático (TPS) es un trastorno hipercinético del movimiento poco frecuente secundario a la interrupción de la vía dentato-rubro-olivar por una lesión en el tronco encefálico o el cerebelo. Métodos: Describimos una cohorte de pacientes consecutivos con TPS que fueron evaluados por un mismo neurólogo en un centro de tercer nivel. Resultados: Se incluyeron un total de 27 pacientes entre 1998 y 2016; 16 hombres y 11 mujeres, con una edad media de

Correspondence:

José L. Ruiz-Sandoval

E-mail: jorulej-1nj@ prodigy.net.mx
Available online: $21-10-2020$ Rev Mex Neuroci. 2020;21(5):199-204 www.revmexneurociencia.com 1665-5044/ @ 2020 Academia Mexicana de Neurología A.C. Published by Permanyer. This is an open access article under the CC BY-NC-ND license (http://creativecommons.org/licenses/by-nc-nd/4.0/). 
47 años (rango 19-89 años). El tiempo promedio desde la lesión inicial hasta el diagnóstico de MPS fue de 14.5 meses (rango 2-48 meses). La etiología principal del TPS fue la enfermedad cerebrovascular (EVC) con 21 (78\%) pacientes. Otras etiologías incluyeron: enfermedades infecciosas y desmielinizantes del sistema nervioso central. El caso restante presentó ataxia progresiva de probable etiología neurodegenerativa. Veintiséis pacientes tenían antecedentes de lesión en fosa posterior. Todos los pacientes tenían signos romboencefálicos con disartria severa y ninguno de los pacientes respondió significativamente al tratamiento farmacológico. Conclusión: EI TPS es un hallazgo más común de lo esperado, principalmente en pacientes con lesión de fosa posterior secundaria a EVC. El principal síndrome clínico fue el romboencefálico con predominio de disartria. No hubo tratamiento efectivo en ninguno de los pacientes.

Palabras clave: Disartria. Triangulo de Guillan-Mollaret. Trastorno hipercinético del movimiento. Temblor palatino. Síndrome romboencefálico.

\section{Introduction}

Symptomatic palatal tremor (SPT) is an uncommon hyperkinetic movement disorder ${ }^{1}$. The pathophysiological basis of SPT is hypertrophic olivary degeneration (HOD), causing interruption of the dentato-rubro-olivary pathway due to lesions in the olivary body at the medulla oblongata. These lesions usually affect the Guillain-Mollaret triangle (GMT) formed by the red nucleus, the inferior olivary nucleus (ION), and the dentate nucleus². The interruption of the cerebellar inhibitory output to the ION gradually causes hypertrophy, leading to abnormal neuronal discharges and subsequent tremor ${ }^{3}$. In SPT, the levator veli palatini is the main affected muscle, causing a 1-2 $\mathrm{Hz}$ palatal tremor that usually persists during sleep; other signs such as ocular, pharyngeal or rubral tremor, ataxia, and pendular nystagmus can also be present ${ }^{4,5}$.

Although sometimes considered myoclonus, its rhythmic nature and bilateral, symmetrical affection of the soft palate and pharynx is consistent with a tremor. Rhythmic myoclonus is often slower than tremor, is present at rest, is not modified significantly by voluntary movements, and often persists during sleep $p^{6,7}$.

The average reported time between an initial GMT lesion and SPT development is 10-11 months ${ }^{8}$.

SPT reports in the past have described it as a medical curiosity, but this could be due to a low level of diagnostic suspicion and late-onset appearance ${ }^{8,9}$.

\section{Methods}

We describe a large cohort of consecutive patients with SPT who were assessed by the same neurologist in a tertiary referral center, including clinical findings, diagnostic workup, and treatment. Subsequent patients $>18$ years with an oscillatory palatal tremor of $1-2 \mathrm{~Hz}$ and history of posterior fossa disease were included. All patients included were evaluated for treatment response with a mean follow-up of 11 months.
The study was approved by the local ethical committee and classified as a non-risk study with no intervention. Clinical, images, or video film records were obtained from corresponding patient authorization by written consent in all cases.

\section{Results}

A total of 27 patients were included in this cohort from 1998 to 2016; 16 males and 11 females, with a mean age of 47 (range 19-89 years). The average time from presentation to the diagnosis of SPT was 14.5 months (range 2-48 months). The main etiology of SPT was cerebrovascular disease (CVD) with 21 (78\%) patients, of which $14(66 \%)$ were classified as ischemic. There were $3(11 \%)$ cases related to infectious diseases: one case due to neurocysticercosis of the fourth ventricle and two others secondary to cerebral toxoplasmosis (in the context of HIV infection) of the posterior fossa. Two females (7\%) had brainstem lesions due to neuromyelitis optica spectrum disorder (NMOSD). The remaining case was a young man with progressive ataxia with a probable neurodegenerative disease. Inferior olivary degeneration (T2 sequence hyperintensity on magnetic resonance imaging [MRI]) with or without hypertrophy was observed in 13 of 14 (93\%) patients who had available MRI performed at follow-up (Figs 1-3). Except for the patient with progressive ataxia, all other 26 patients had a history of injury to the posterior fossa, in addition to rhombencephalic signs, including severe spastic or ataxic dysarthria. None of the patients responded significantly to pharmacological treatment during the follow-up (specific treatment is described in Table 1).

\section{Discussion}

Since its first report by Oppenheim in 1887, HOD continues to be an uncommon condition with a variety 


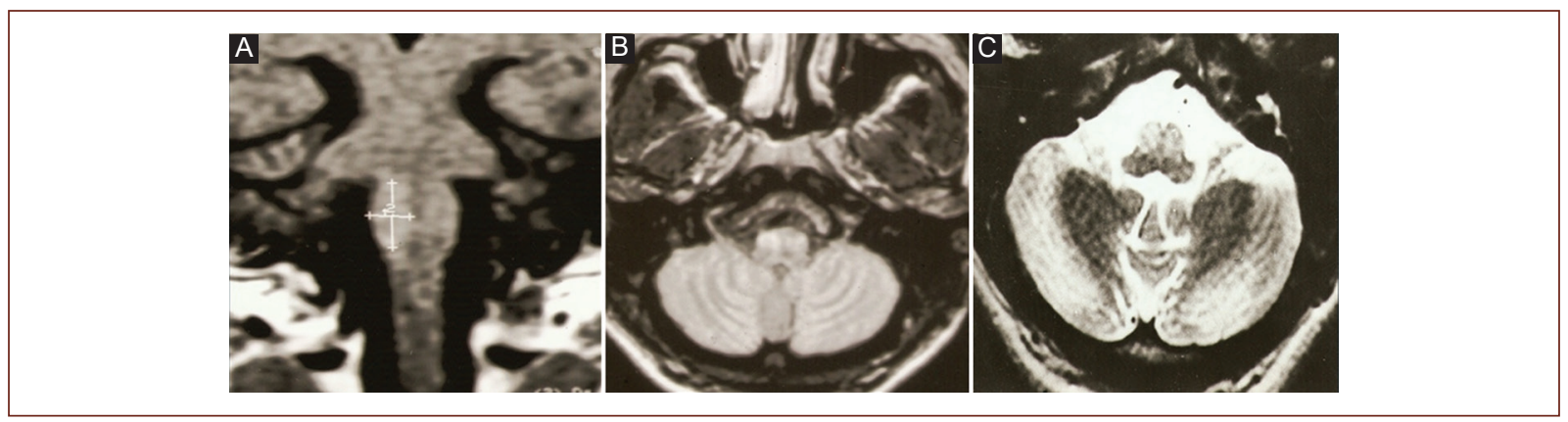

Figure 1. (Patient 2) Magnetic resonance imaging. Coronal T1 A: axial FLAIR B: and axial T2 C: weighted imaging showing olivary hypertrophy degeneration in a patient with progressive ataxia.

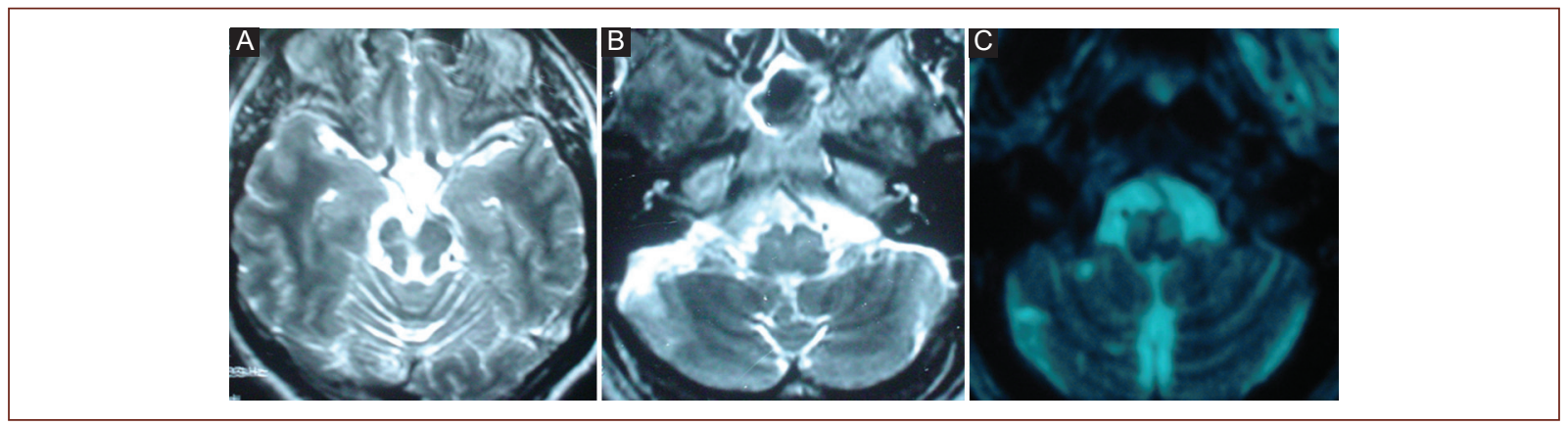

Figure 2. (Patient 18) Magnetic resonance imaging. Axial T2-weighted imaging A-C: showing multiple, chronic infarctions in the vertebrobasilar territory (cerebellum and mesencephalon), and olivary hypertrophy.

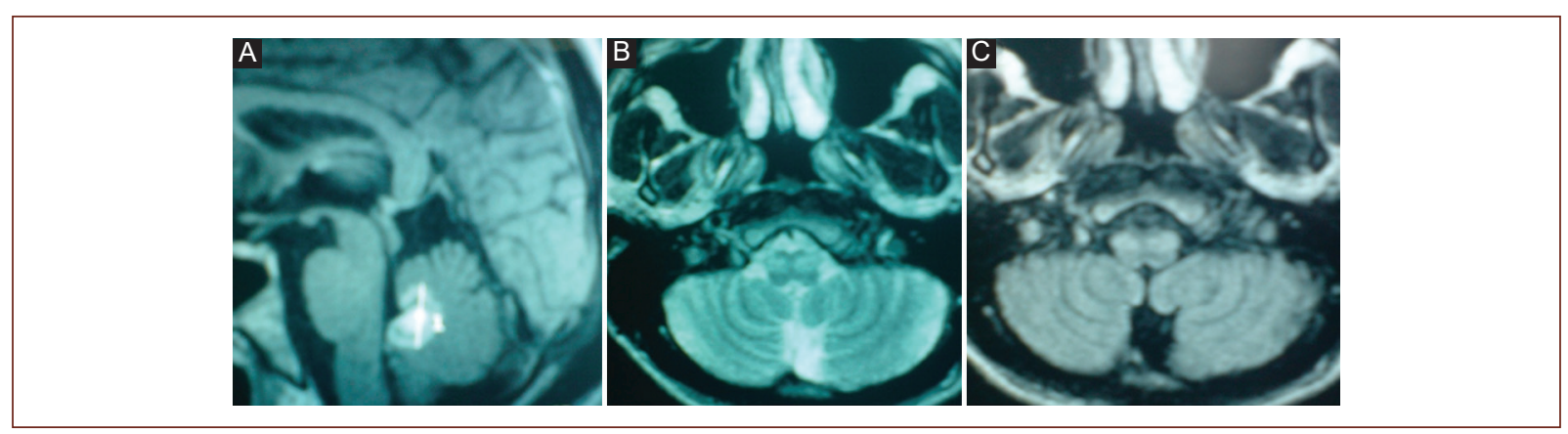

Figure 3. (Patient 20) Magnetic resonance imaging (MRI). Ring enhancement on sagittal T1 contrast-enhanced weighted imaging in the fourth ventricle A: consistent with toxoplasmosis in a patient with HIV, axial T2 B: and FLAIR C: with olivary hypertrophy 11 months after follow-up.

of etiologies and clinical manifestations, with palatal tremor as a unifying criterion ${ }^{10}$.

In this study spanning almost two decades, our neurology staff was able to identify approximately 1.5 new cases of SPT per year using the following approach: a history of posterior fossa disease, a careful physical examination, and ordering appropriate neuroimaging studies; making SPT a more common condition than previously reported ${ }^{6,7}$. Patients with a history of posterior fossa surgery were not included in our registry, making this condition probably more frequent in neurosurgery departments. Clinically, the HOD can also cause dentato-rubral tremor (Holmes tremor) and ocular myoclonus as late-onset manifestations; however, 
Rev Mex Neuroci. 2020;21(5)

Table 1. Symptomatic palatal tremor etiologies, time to diagnosis, treatment, outcome, and MRI findings

\begin{tabular}{|c|c|c|c|c|c|c|c|}
\hline No. & Sex/age & $\begin{array}{l}\text { Etiology (initial } \\
\text { neurological insult) }\end{array}$ & $\begin{array}{l}\text { Time to diagnosis } \\
\text { (months) }\end{array}$ & Treatment & $\begin{array}{l}\text { Follow-up } \\
\text { (months) }\end{array}$ & $\begin{array}{l}\text { Palatal tremor } \\
\text { outcome }\end{array}$ & $\begin{array}{l}\text { MRI inferior olivary } \\
\text { hyperintensity/ hypertrophy }\end{array}$ \\
\hline 1 & $\mathrm{M} / 48$ & Cerebellar infarct & 24 & Propranolol & 4 & Unsuccessful & Yes \\
\hline 2 & $M / 34$ & Progressive ataxia & 11 & $\begin{array}{l}\text { Clonazepam/ } \\
\text { botulinum toxin }\end{array}$ & 6 & $\begin{array}{l}\text { Decrease in } \\
\text { frequency }\end{array}$ & Yes \\
\hline 3 & $M / 25$ & $\begin{array}{l}\text { Multiple infarcts in } \\
\text { vertebrobasilar territory }\end{array}$ & 9 & None & 8 & Unsuccessful & Yes \\
\hline 4 & $F / 25$ & $\begin{array}{l}\text { Multiple infarcts in } \\
\text { vertebrobasilar territory }\end{array}$ & 12 & Clonazepam & 10 & Unsuccessful & Yes \\
\hline 5 & $F / 47$ & $\begin{array}{l}\text { Right cerebellar } \\
\text { hypertensive hemorrhage }\end{array}$ & 36 & None & 36 & Unsuccessful & Yes \\
\hline 6 & $\mathrm{M} / 41$ & $\begin{array}{l}\text { Cerebellar peduncular } \\
\text { hemorrhage }\end{array}$ & 13 & Propranolol & 4 & Unsuccessful & Unknown \\
\hline 7 & $F / 75$ & Mesencephalic infarct & 8 & $\begin{array}{l}\text { Propranolol/ } \\
\text { levetiracetam }\end{array}$ & 14 & Unsuccessful & Unknown \\
\hline 8 & $M / 89$ & Cerebellar infarct & 9 & $\begin{array}{l}\text { Propranolol/ } \\
\text { levetiracetam }\end{array}$ & 2 & Unsuccessful & Unknown \\
\hline 9 & $M / 24$ & $\begin{array}{l}\text { Multiple infarcts in } \\
\text { vertebrobasilar territory }\end{array}$ & 10 & None & 3 & Unsuccessful & Unknown \\
\hline 10 & $M / 64$ & $\begin{array}{l}\text { Cerebellar hypertensive } \\
\text { hemorrhage }\end{array}$ & 24 & $\begin{array}{l}\text { Propranolol/ } \\
\text { levetiracetam }\end{array}$ & 13 & Unsuccessful & Yes \\
\hline 11 & $\mathrm{M} / 28$ & $\begin{array}{l}\text { Multiple infarcts in } \\
\text { vertebrobasilar territory }\end{array}$ & 12 & $\begin{array}{l}\text { Acetazolamide/ } \\
\text { levetiracetam }\end{array}$ & 25 & $\begin{array}{l}\text { Decrease in } \\
\text { frequency }\end{array}$ & Yes \\
\hline 12 & $\mathrm{~F} / 20$ & Cerebellar hemorrhage & 11 & Propranolol & 8 & Unsuccessful & Unknown \\
\hline 13 & $F / 34$ & $\begin{array}{l}\text { Fourth ventricle } \\
\text { neurocysticercosis }\end{array}$ & 48 & Propranolol & 1 & Unsuccessful & Unknown \\
\hline 14 & $\mathrm{M} / 46$ & $\begin{array}{l}\text { Multiple infarcts in } \\
\text { vertebrobasilar territory }\end{array}$ & 17 & None & 4 & Unsuccessful & Unknown \\
\hline 15 & $F / 19$ & $\begin{array}{l}\text { Thalamomesencephalic } \\
\text { hemorrhage }\end{array}$ & 29 & Propranolol & 8 & $\begin{array}{l}\text { Speech } \\
\text { improvement }\end{array}$ & No \\
\hline 16 & $\mathrm{M} / 78$ & Cerebellar infarct & 8 & Propranolol & 9 & Unsuccessful & Unknown \\
\hline 17 & $\mathrm{M} / 70$ & $\begin{array}{l}\text { Pontine hypertensive } \\
\text { hemorrhage }\end{array}$ & 5 & Propranolol & 5 & Unsuccessful & Unknown \\
\hline 18 & $\mathrm{M} / 43$ & $\begin{array}{l}\text { Multiple infarcts in } \\
\text { vertebrobasilar territory }\end{array}$ & 12 & Propranolol & 19 & Unsuccessful & Yes \\
\hline 19 & $F / 61$ & $\begin{array}{l}\text { Multiple infarcts in } \\
\text { vertebrobasilar territory }\end{array}$ & 2 & Propranolol & 9 & Unsuccessful & Unknown \\
\hline 20 & $M / 35$ & $\begin{array}{l}\text { Toxoplasmosis of } \\
\text { cerebellum and roof of } \\
\text { fourth ventricle }\end{array}$ & 11 & Propranolol & 7 & Unsuccessful & Yes \\
\hline 21 & $\mathrm{M} / 56$ & $\begin{array}{l}\text { Multiple infarcts in } \\
\text { vertebrobasilar territory }\end{array}$ & 6 & None & 5 & Unsuccessful & Unknown \\
\hline 22 & $F / 68$ & $\begin{array}{l}\text { Multiple infarcts in } \\
\text { vertebrobasilar territory }\end{array}$ & 10 & $\begin{array}{l}\text { Propranolol / } \\
\text { levodopa / } \\
\text { biperidene }\end{array}$ & 8 & Unsuccessful & Unknown \\
\hline 23 & $M / 56$ & $\begin{array}{l}\text { Multiple infarcts in } \\
\text { vertebrobasilar territory }\end{array}$ & 18 & Nifedipine & 3 & Unsuccessful & Unknown \\
\hline 24 & $F / 56$ & $\begin{array}{l}\text { Brainstem and } \\
\text { diencephalic hemorrhage }\end{array}$ & 16 & $\begin{array}{l}\text { Propranolol } \\
\text { Levetiracetam }\end{array}$ & 16 & Unsuccessful & Yes \\
\hline
\end{tabular}


Table 1. (Continued)

\begin{tabular}{|l|c|l|c|l|c|l|c|}
\hline No. & Sex/age & $\begin{array}{l}\text { Etiology (initial } \\
\text { neurological insult) }\end{array}$ & $\begin{array}{c}\text { Time to diagnosis } \\
\text { (months) }\end{array}$ & Treatment & $\begin{array}{c}\text { Follow-up } \\
\text { (months) }\end{array}$ & $\begin{array}{l}\text { Palatal tremor } \\
\text { outcome }\end{array}$ & $\begin{array}{l}\text { MRI inferior olivary } \\
\text { hyperintensity/ hypertrophy }\end{array}$ \\
\hline 25 & F/48 & $\begin{array}{l}\text { Neuromyelitis optica } \\
\text { spectrum disorder }\end{array}$ & 12 & None & 38 & Unsuccessful & Yes \\
\hline 26 & F/63 & $\begin{array}{l}\text { Neuromyelitis optica } \\
\text { spectrum disorder }\end{array}$ & 9 & Carbamazepine & 16 & Unsuccessful & Yes \\
\hline 27 & M/40 & $\begin{array}{l}\text { Toxoplasmosis in } \\
\text { posterior fossa (HIV +) }\end{array}$ & 12 & None & 8 & Unsuccessful & Yes \\
\hline
\end{tabular}

M: male; F: female.

these symptoms did not occur in any of our patients during follow-up ${ }^{2,11}$.

In our study, the most common cause of SPT was brainstem or cerebellar CVD, representing almost $80 \%$ of reported cases. These data are consistent with results from other studies, in which the main causes of SPT were CVD, trauma, metastatic, and astrocytic tumors, multiple sclerosis, surgical interventions, syringobulbia, Behçet's disease, and encephalitis ${ }^{12-14}$.

Although most of the patients with HOD and SPT have no symptomatic discomfort, several drugs, including beta-blockers, antiepileptic, benzodiazepines, and neuroleptics, are commonly used ${ }^{12}$. They usually offer partial and non-sustained symptom control in most cases, as reported in this study. Some recent models have demonstrated the influence of cerebellar Purkinje-cell modulation to the hypertrophic ION in SPT, suggesting drug combination therapy for a "double" inhibition with more satisfactory results. These therapies include the use of drugs with GABA-enhancing inhibitory and glutamatergic-coupling effects ${ }^{15}$.

Other non-pharmacological options include the administration of botulinum toxin, a safe and effective therapy in selected patients with SPT, and marginal benefits using special dental devices that have been used by some authors in patients with lingual-palatal tremor ${ }^{16-18}$.

Deep brain stimulation has not been studied in SPT but is a secure and beneficial procedure in other movement disorders such as essential tremor and Parkinson's disease. It could provide some benefit for SPT in the future ${ }^{19,20}$.

Patients with a history of brainstem or cerebellar injury with no palatal tremor at diagnosis should be kept under vigilance since SPT can appear during follow-up, up to 30 months after initial presentation. Patients with an incidental finding of palatal tremor should be evaluated to rule out lesions in the posterior fossa since over $75 \%$ of cases reveal an underlying symptomatic cause ${ }^{21}$. This could be a typical scenario of patients with undiagnosed multiple sclerosis or NMOSDs who initially present with posterior fossa symptoms and visit another specialist (such as an otorhinolaryngologist) for medical advice.

During the study, we have been able to identify three clinical characteristics that may facilitate and increase a diagnosis of SPT: (1) history of posterior fossa disease; (2) persistence of severe rhombencephalic signs during the $1^{\text {st }}$ year of symptom onset; and (3) predominance of severe spastic or ataxic dysarthria. More prospective studies with consecutive clinical evaluations should be done to determine the predictive factors involved in these reported findings.

\section{Conclusion}

In conclusion, SPT is not as rare as previously reported, and physicians should be aware of associated signs and symptoms for adequate diagnosis, especially in patients with a history of posterior fossa disease.

\section{Acknowledgment}

Partial information was presented as a poster in the Annual Meeting of the American Academy of Neurology, 2008 (Chicago II) Abst pag.

\section{Funding}

This research has not received any specific grant from agencies in the public, commercial, or non-profit sectors.

\section{Conflicts of interest}

None to report. 


\section{Ethical disclosures}

Protection of human and animal subjects. The authors declare that the procedures followed were in accordance with the regulations of the relevant clinical research ethics committee and with those of the Code of Ethics of the World Medical Association (Declaration of Helsinki).

Confidentiality of data. The authors declare that they have followed the protocols of their work center on the publication of patient data.

Right to privacy and informed consent. The authors have obtained the written informed consent of the patients or subjects mentioned in the article. The corresponding author is in possession of this document.

\section{References}

1. Deuschl G, Toro C, Valls-Solé J, Zeffiro T, Zee DS, Hallett M. Symptomatic and essential palatal tremor. 1. Clinical, physiological and MR analysis. Brain. 1994;117:775-88.

2. Wang H, Wang Y, Wang R, Li Y, Wang P, Li J, et al. Hypertrophic olivary degeneration: a comprehensive review focusing on etiology. Brain Res. 2019;1718:53-63.

3. Nishie M, Yoshida Y, Hirata Y, Matsunaga M. Generation of symptomatic palatal tremor is not correlated with inferior olivary hypertrophy. Brain. 2002;125:1348-57.

4. Jamieson DR, Mann C, O'Reilly B, Thomas AM. Ear clicks in palatal tremor caused by activity of the levator veli palatini. Neurology. 1996;46:1168-9.
5. Deuschl G, Toro C, Hallett M. Symptomatic and essential palatal tremor. 2. Differences of palatal movements. Mov Disord. 1994;9:676-8.

6. Park HD, Kim HT. Electrophysiologic assessments of involuntary movements: tremor and myoclonus. J Mov Disord. 2009;2:14-7.

7. Tilikete C, Desestret V. Hypertrophic olivary degeneration and palatal or oculopalatal tremor. Front Neurol. 2017;8:302.

8. Deuschl G, Mischke G, Schenck E, Schulte-Mönting J, Lücking $\mathrm{CH}$. Symptomatic and essential rhythmic palatal myoclonus. Brain. 1990;113:1645-72.

9. Pearce J. Palatal myoclonus. Proc R Soc Med. 1969;62:267.

10. Oppenheim $\mathrm{H}$. Uber olivendegeneration bei atheromatese der basalen himarterien. Berl Klin Wochenschr. 1887;34:638-9.

11. Menéndez DF, Cury RG, Barbosa ER, Teixeira MJ, Fonoff ET. Hypertrophic olivary degeneration and holmes' tremor secondary to bleeding of cavernous malformation in the midbrain. Tremor Other Hyperkinet Mov (N Y). 2014;4:264.

12. Choi SM. Movement disorders following cerebrovascular lesions in cerebellar circuits. J Mov Disord. 2016;9:80-8.

13. Khoyratty $F$, Wilson $T$. The dentato-rubro-olivary tract: clinical dimension of this anatomical pathway. Case Rep Otolaryngol. 2013;2013:934386.

14. Walsh RA, Gillivan-Murphy P, Murphy C, Colreavy M, O'Rourke K, Lynch T. Bilateral cerebellar stroke presenting with acute dysphonia and late palatal tremor. Mov Disord. 2012;27:346-8.

15. Shaikh AG, Hong S, Liao K, Tian J, Solomon D, Zee DS, et al. Oculopalatal tremor explained by a model of inferior olivary hypertrophy and cerebellar plasticity. Brain. 2010;133:923-40.

16. Penney SE, Bruce IA, Saeed SR. Botulinum toxin is effective and safe for palatal tremor: a report of five cases and a review of the literature. $J$ Neurol. 2006;253:857-60.

17. Mittal SO, Lenka A, Jankovic J. Botulinum toxin for the treatment of tremor. Parkinsonism Relat Disord. 2019;63:31-41.

18. Mondria T, de Gier HH, Boon AJ. New device to control combined lingual and palatal myoclonus. Mov Disord. 2007;15:573-6.

19. Puschmann A, Wszolek ZK. Diagnosis and treatment of common forms of tremor. Semin Neurol. 2011;31:65-77.

20. Martinez-Ramirez D, Ramirez-Zamora A, Rodríguez-Violante R. Estimulación cerebral profunda: hacia la generación de los dispositivos "inteligentes". Rev Mex Neuroci. 2016;17:67-77.

21. Pearce JM. Palatal myoclonus (syn. palatal tremor). Eur Neurol. 2008:60:312-5. 